\title{
Banking Sector Development, Inflation and Economic Growth in Asian Countries: A Panel Causality and Co-Integration Approach
}

\author{
Muhammad Imran Nazir (Corresponding author) \\ Ph.D. Scholar, Zhongnan University of Economic and Law, China \\ E-mail: imran.n13@outlook.com \\ Rehana Tabassam \\ Preston University Islamabad, Pakistan \\ Ifran Khan \\ MS Scholar (Finance), IFAS: Xiamen University, China \\ Muhammad Rizwan Nazir \\ Ph.D. Scholar, Zhongnan University of Economic and Law, China
}

Received: October 17, 2018 Accepted: December 5, 2018 Published: December 11, 2018

doi:10.5296/ijafr.v8i4.14046

URL: https://doi.org/10.5296/ijafr.v8i4.14046

\begin{abstract}
This study investigates the causal relationship between banking sector development, inflation, and economic growth for six Asian countries (Bangladesh, China, India, Malaysia, Pakistan and Sri Lanka) over the period of 1970-2016. Using a Pedroni panel, Kao co-integration test, Panel Granger causality-based Error Correction Model, Dynamic ordinary least square (DOLS), and Fully modified ordinary least square (FMOLS), this study finds that the development of the banking sector generally has a positive relationship with economic growth in the long-run. This results show that in the long-run, monetary policy play a vital role in the economic growth. This study also confirmed the response causality between the indicators of banking sector development and economic growth. Based on the empirical
\end{abstract}


findings, this research provides important policy implications to the banking sector and economic supervisory bodies in order to achieve the long run economic growth.

Keywords: Banking sector development, Panel granger causality, Inflation, Economic growth, Asian countries

JEL Classifications: C23, G21, O3, O31, O33

\section{Introduction}

The global economy has experienced the extraordinary change over the last three decades, in part motorized by prompt expansions in and transmission of information and communication technology (ICT) across the world. These elements of ICT innovations have empowered the main regions of the economy and countries across the world to be more independent and interlocking on one another. One of the main economic zones that have incorporated the digital insurrection is the financial sector, which contain of the banking and other industries. The integration of these industries which is powered by the ICT insurrection has supported them to construct a stronger multiplier effect, as well a greater degree of economies of scope and scale. The inter-locking of regions and countries also posture their individual challenges in that, any instability in one economy has the potential to resonate across the other regions of the economy which may lead to a contagion outcome.

It is well recognized in the literature of finance growth that financial expansions contribute to the growth of the economy by direct and indirect networks. The financial extending increases the supply of capital and assists the apportionment of financial funds to investment and the other productive actions. On a broader level, well-structuring banks and capital markets contribute to a more effectual distribution of funds as well as to innovation and other dynamic proficiency gains over time. In addition, the financial region directly delivers valuable and growth-promoting facilities. Therefore, it supports to ascertain a profitable business opportunities and to develop the corporate governance (Levine 2005).

The objective of this study is intended to throw different sight on the relations among the financial region development and economic growth. Precisely, this study is highpoint of two prominent variables: expansion of the banking region and inflation. This study also uses five particular measures of the banking-region development and reports the results on economic growth separately. It has been documented that the economic uncertainty expressed an extraordinary inflation has an imperative posture on the economic expansion. Additionally, the different researchers have used diverse indicators of financial progress to support the economic growth (Shan et al., 2001; Levine, 2003; Chang and Caudill, 2005; Trew, 2006; Ang, 2008; Gries et al., 2009; Chaiechi, 2012; Petkovsk \& Kjosevsk, 2014). Therefore, the financial region progress can be interrelated to the inflation. For example, the easier loaning practices might have concerns for prices economy-wide. So, the financial expansion might affect the growth directly by the normal spending networks and indirectly by its influence on inflation.

King and Levine (1993a) advocated that the valuable effects on investment and progress from the presence of wide-ranging markets. Barro and Sala-i-Martin (1995) emphasized that the 
growth of these markets is endogenous since they are a systematic part of the progression of growth. So, the financial improvement might clue to the growth, which is the latter might lead to further progress. The development of financial region may also be related to inflation on a theoretical grounds: the expansion means that the customer can easily borrow and then cheaper way to buy the different goods, which enlarge the demand for particular goods. In this way the prices increases faster than they would otherwise. The progress of financial region supports the organizations in retrieving a capital in an easier way which increases the demand for the particular goods (include energy) that the organizations want to function their business, which has the magnitudes of inflation.

The financial growth is generally explained in terms of amassed size of the financial region, its sectorial structure, and a range of attributes of its separate sub-regions that control their efficiency in meeting the different economic mediators' necessities to improve their wealth. The main important financial organizations contains the pension funds, saving organizations, mortgage institutions, commercial banks, central banks, stock exchange markets and other financial market organizations (Zaman et al., 2012). So, the financial progress-economic growth relation signifies all actions undertaken by the above-mentioned financial organizations and their association with the economic growth (Levine 2005). The theory of endogenous growth as expressed as (Beck et al. 2000; Levine et al., 2002; Ghirmay, 2004; Levine, 2005; Wolde-Rufael 2009; Hassan et al. 2011; Zhang et al., 2012; Hsueh et al., 2013) and others strains that the financial progress is the main part in development long run economic growth later it accelerates the competent inter-temporal distribution of funds, capital amassing and the high-tech innovation.

The perception of financial development is impartially wide-ranging, this study focus on the development in the banking region. Therefore, this paper explore that the causal relations among the progress of banking-region, inflation and the economic growth. As opposing to the previous work, our study emphases of the causal relations between the three variables using the panel co-integration and causality assessments on a sample of 6 Asian countries over the period of 1970-2016. The innovative panel-data assessment technique permits for more robust estimations by using the deviations among the countries as well as the time variation. We find the stimulating and relevant causal relations between the variables stemming the distinctively from our innovations.

The remaining part of the paper is structured as follows. Section 2 discusses an overview of the review of literature: which one scrutinizing the relationship among the development of banking-sector and economic growth and the other one sightseeing the nexus among the inflation and economic growth. Section 3 explains the five indicators of banking-sector development and the data sourced used in this study. Section 4 outlines the proposed empirical methodology and also the explaining the results. Section 5 provides the conclusion and policy implications for this research.

\section{Review of Literature}

The exploration of this research is to determine the factors of banking sector development effect on the inflation and the economic growth. We chose five proxy money-base variables 
to represent the banking sector development of the Asian countries, and other variables due to well-established theories and the outcomes from the literature as well as the availability of data.

Over the past few periods, specifically the role of the banking region improvement in supporting the economic growth has received considerable responsiveness with different theoretical and experimental research works (King et al., 1993b; Levine, 2005; Chang \& Caudill, 2005; Ang, 2008; Petkovsk \& Kjosevsk, 2014; Tripathy \& Pradhan, 2014). The different researchers have used the numerous variables such as the ratio of financial deposit to GDP, private credit and liquid liabilities, concentration percentage, net interest margin, cost of bank overhead and cost income ratio as a proxies for the level of banking region development. Although a substantial experimental literature on this area, the direction of the causal effect through the development of banking sector and economic growth has been debatable. Therefore, it is still open question whether the improvement of banking sector enhances the economic growth or whether the growth pushes the improvement of the banking sector. An analysis of four conceivable hypotheses and conforming the experimental results.

The first one is the supply-leading hypothesis, which resists that the improvement of the banking sector is an essential pre-requisite to the growth (King et al., 1993a, b). Therefore, the causality rounds from development of the banking region to economic growth. The exponents of this hypothesis uphold that improvement of the banking sector might include the greater economic growth by straightly facilitating and accumulative savings in the form of financial assets, thus laying the capital materialization which leads to supporting the economic growth (Levine et al., 2000; Christopoulos \& Tsionas, 2004; Abu-Bader et al., 2008b). The influence of the banking region on the actual side of the economy can barely be over-emphasized. Certainly, Liang \& Teng (2006) and Calderon \& Liu, (2003) quote the Goldsmith (1969), statuses that "one of the highest imperative difficulties in finance is the influence that the conformation of the banking and financial improvement on growth".

The other one is the demand-following hypothesis, which recommends the causality rounds instead from growth to development of financial region. The followers of this hypothesis advocate that the improvement of the banking region plays only an inconsequential in economic growth and that it is just effect of growing in the economy (Goldsmith, 1969; Liang \& Teng, 2006; Gries et al., 2009). The indication is that as the economy develops, further banking organizations', banking products and services appear in the market in reaction to upper demand for financial services. Therefore, the deficiency of banking organization's in emerging regions designates a lack of demand for their facilities. So, as the economy transmits, the financial scheme progresses more advance, thus aggregate the chances for investment and diversifying the risk (Ang, 2008; Gries et al., 2009).

The next one is feedback hypothesis, which proposes that the economic growth and development of the banking region can complement and emphasize each other, constructing this development and economic growth by jointly causative. The deviation of bidirectional causality is that the development of banking sector is essential to economic growth and the growth predictably involves an established financial scheme (Khan, 2001; Shan et al., 2001; 


\section{Macrothink}

International Journal of Accounting and Financial Reporting

ISSN 2162-3082

Calderon \& Liu, 2003; Odhiambo, 2007; Wolde-Rufael, 2009; Hassan et al., 2011; Pradhan et al., 2013a; Tripathy \& Pradhan, 2014). The last one is the neutrality hypothesis, this hypothesis contend that the development of the banking region and growth are independent of each other. The studies supporting this hypothesis are (Al-Yousif, 2002; Pradhan et al., 2013b).

There is an empirical studies of the causality among the inflation and the growth. Some of the studies showed an affirmative relation among the inflation and growth (Hwang, 2001), while the other studies showed a negative association among these two variables (Arai et al., 2004; Adam \& Bevan, 2005). Nguyen \& Wang (2010) documented that the presence of a response causal relationship among these variables. There is also exist a mixed results, which needs to further empirical investigation and this study also incorporate this possible causal relationship among the inflation and growth. This study suggesting that the improvement of the banking region and inflation might be interrelated to economic growth (Andres et al., 2004; Fountas \& Karanasos, 2007; Naceur \& Ghazouani, 2007; Wu, Hou, \& Cheng, 2010; Sunde, 2012). Therefore, this study is used Pedroni's panel cointegration test to expose whether these three variables are cointegrated and also there is a long run equilibrium association among them. This study is also used a panel Granger causality test to show new empirical confirmation among these variables. There are some contributions for the existing literature. First, this study is used the sample of main Asian countries over a long period (1970-2016). The other one is that this study is used different econometric techniques and empirical approaches to answer these questions which are related of the casual association between the variables.

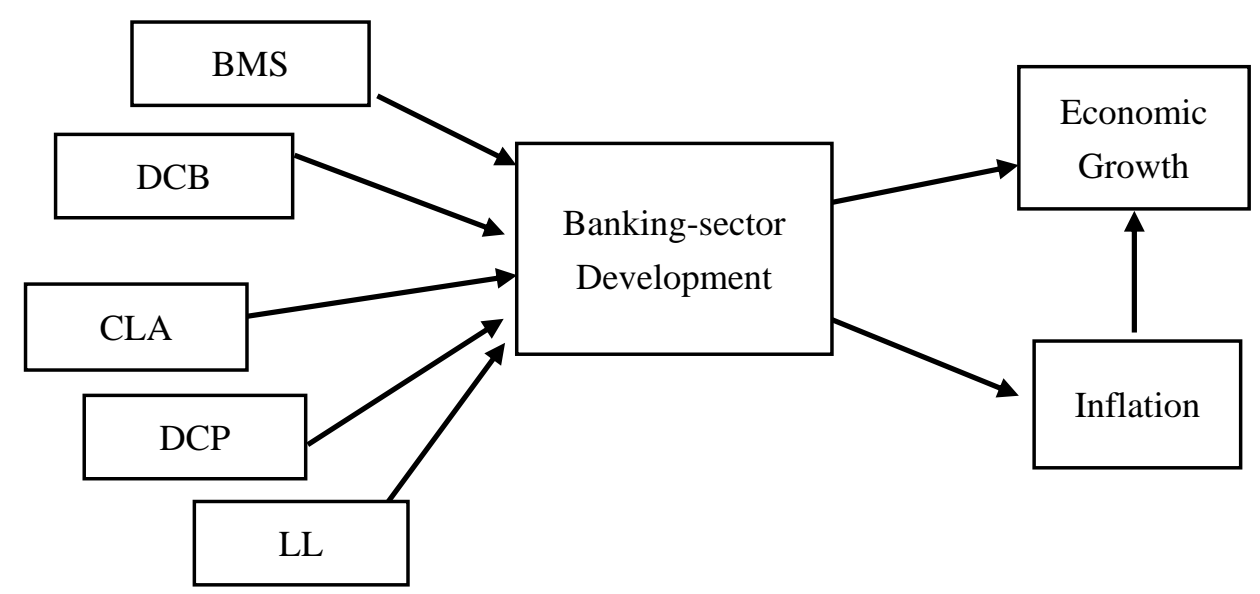

Figure 1. Coceptual framewrok

\section{Variables and Data Source}

The growth of the banking region means a procedure that developments in the quantity, excellence and competence of the services have progressed to create monetary aggregates measured in this research noticeable in relative to total income. This procedure includes the collaboration of different actions and therefore cannot be apprehended by a particular measure (Rousseau \& Wachtel, 1998; Beck \& Levine, 2004; Abu-Bader et al., 2008b). This study is used five different proxy measures for banking-region improvement: the broad 
money supply (BMS), domestic credit provided by the banking sector (DCB), claims on assets (CLA), domestic credit to private region (DCP), and the liquid liabilities (LL) as the percentage of GDP. The explanation of variables are shown in Table 1, and also explain the economic growth and the inflation. All of the related data on variables are attained from the World Development Indicators. Figure 1 indications the theoretical framework concerning all the variables. The banking region growth is exemplified by one of our five recognized proxy variables. So, by all of the proxy variables in the one same equation might lead to the problem of multicolinearity. Therefore, this study uses the each of variables individually.

The experimental examination is constructed on a panel of 6 main Asian countries: Pakistan, China, India, Sri Lanka, Bangladesh, and Malaysia, over the period of 1970-2016. All of these countries are selected on the origin of data accessibility. This study involve the comprehensive and continuous time series on all the variables for a time period of 47 years. All of the variables used are converted to their natural log for our assessments.

Table 1. Definition of all variables

\section{Variables Definition}

BMS This is broad money supply expressed as a percentage of GDP.

DCB Domestic Credit provided by banking region, expressed as a percentage of GDP. This credit provided by banking region contains all credit to different regions on a gross basis. This region includes banking organizations such as monetary experts, building loan associations.

CLA Claims on Asset as a percentage of GDP, which include loans to central government organizations.

DCP Domestic credit to private sectors as a percentage of GDP, which means all credit mentions to financial resources provided by the private region.

LL This is liquid liabilities as percentage of GDP. This LL contains commercial paper, deposits, currency and shares of mutual funds.

PGDP This is growth rate of per capita income (in percentage), this income as a GDP and a measure of growth.

INF This is inflation rate (in percentage), which is calculated by the consumer price index.

Notes: All of the measures are in US\$. All of the variables are well-defined in WDI. This study uses the natural log of all variables for further analysis. 


\subsection{Descriptive Statistics}

Table 3, the descriptive statistics during the period of 1970 to 2016 of all the variables which are used in this study. The average broader money supply and claim on assets are $3.26 \%$ and $1.39 \%$ of the GDP. The possible deviation from its mean was 3.24 and 1.46 respectively. The average value of domestic credit provided by the banking sector, liquid liabilities, and the domestic credit provided by the private sector was $3.40,3.28$, and $2.59 \%$ of the GDP, whereas the maximum values of these variables are 4.11, 4.09, and 3.79, the minimum values are $2.25,2.41$, and 0.240 respectively.

Table 2. Descriptive statistics

\begin{tabular}{lccccccc}
\hline Variables & Mean & Med & SD & Min & Max & Skew & Kur \\
BMS & 3.26 & 3.24 & 0.59 & 2.12 & 4.18 & 0.01 & 1.80 \\
CLA & 1.39 & 1.46 & 1.20 & -1.74 & 2.79 & -0.71 & 2.82 \\
DCB & 3.40 & 3.28 & 0.54 & 2.25 & 4.11 & -0.04 & 1.66 \\
DCP & 2.59 & 2.77 & 0.99 & 0.24 & 3.79 & -0.82 & 2.68 \\
LL & 3.28 & 3.25 & 0.52 & 2.41 & 4.09 & 0.17 & 1.61 \\
INF & 1.73 & 1.81 & 0.43 & 0.37 & 2.37 & -1.19 & 4.25 \\
PGDP & 0.90 & 1.11 & 1.03 & -3.41 & 2.73 & -1.90 & 8.07 \\
\hline
\end{tabular}

All of the above variables are explain in table 2 and used the log form for this analysis.

\subsection{Econometric Model and Estimation Strategy}

To scrutinize the long run causal association among the improvement of banking region, inflation and the economic growth, we guesstimate three panel regressions models by using the pooled data on the 6 countries. So, the following (Holtz-Eakin et al., 1988) process, the following regressions are expressed as:

$$
\begin{gathered}
P G D P_{i t}=\eta_{1 j}+\sum_{k=1}^{p} \alpha_{1 i k} \triangle P G D P_{i t-k}+\sum_{k=1}^{q} \beta_{1 i k} \Delta B A K_{i t-k}+ \\
\sum_{k=1}^{r} \delta_{1 i k} \Delta I N F_{i t-k}+\lambda_{i} E C T_{1 i t-1}+\varepsilon_{1 i t} \\
\triangle B A K_{i t}=\eta_{2 j}+\sum_{k=1}^{p} \alpha_{2 i k} \Delta B A K_{i t-k}+\sum_{k=1}^{q} \beta_{2 i k} \Delta P G D P_{i t-k}+ \\
\sum_{k=1}^{r} \delta_{2 i k} \Delta I N F_{i t-k}+\lambda_{2 i} E C T_{2 i t-1}+\varepsilon_{2 i t}
\end{gathered}
$$




\section{Ml Macrothink}

$$
\begin{gathered}
\Delta I N F_{i t}=\eta_{3 j}+\sum_{k=1}^{p} \alpha_{3 i k} \Delta I N F_{i t-k}+\sum_{k=1}^{q} \beta_{3 i k} \Delta B A K_{i t-k}+ \\
\sum_{k=1}^{r} \delta_{3 i k} \Delta P G D P_{i t-k}+\lambda_{3 i} E C T_{3 i t-1}+\varepsilon_{3 i t}
\end{gathered}
$$

Where

$\Delta$ is the first-difference operator which is applied to the variables: $\mathrm{p}, \mathrm{q}$, and $\mathrm{r}$ are the lag lengths;

i shows the country $i$ and $t$ denotes the year in the panel $(i, t=1,2, \ldots, N, T)$;

PGDP is the growth rate;

BAK is the development of the banking region, which has five different proxy variables such as: BMS, DCB, CLA, DCP, and LL;

INF is the inflation rate (Change CPI) in the economy and ECT is the error correction term; and

$\varepsilon_{i t}$ is a error term.

Firstly, this study can appearance for short and long run causal associations among the varaibles. The causal relationship of short run are measured by the F-value and the implication of the lagged changes in the dependent variables. The long run causal relationships among the variables are measured by the significance of t-test of the lagged ECT. Therefore, the equations of 1-3, table 11 shows the different possible hypotheses which is regarding the causal nexus among the development of banking region, inflation, and economic growth. The above econometric description which is explained in all three equation, is expressive if all the variables are integrated of I (1) and cointegrated. So if the concerning variables are I (1) are not cointegrated, then the element of ECT will be removed in the assessment procedure. Consequently, the pre-requisite to the assessment procedure is to square the order of integration and cointegration between the variables. This study employ the Levin-Lin-Chu(LLC) panel unit root test (Levine et al., 2002) and Pedroni panel cointegration test (Pedroni, 2004) to examine for I(1) and cointegration among the each variables. The brief explanation on these two methods seems below.

\subsection{Testing for the Integration}

This study uses the Levin-Lin-Chu (LLC) test to determine the order of integration, where a time series of all variables accomplishes the stationary. The experiment procedures the philosophies of the augmented dickey-Fuller (ADF) test and permits for heterogeneity of the intercepts through the other members of the panel. The equation of this test is expressed as follows:

$$
\Delta Y_{t}=u_{i}+\gamma_{i} Y_{i t-1}+\sum_{j=1}^{q i} \beta_{i j} \Delta Y_{i t-j}+\lambda_{i} t+\varepsilon_{i t}
$$


Where

$\mathrm{t}=1,2 \ldots \ldots \mathrm{N}$ shows the year in the panel; and $\mathrm{i}=1,2 \ldots \ldots \mathrm{N}$ shows the country in the panel;

$\mathrm{Y}_{\text {it }}$ is the series for country $\mathrm{i}$ in year $\mathrm{t}$; and $u_{i}$ shows the country-specific effects;

$\Delta$ is the first difference operator; and qi number of lags which is selected for the ADF regression; and $\varepsilon_{i t}$ is the independently and normally distributed random error.

The model permits for fixed effects, unit-specific time trends, and common time effects. The coefficient of $\beta_{j}$ of the lagged dependent variable is restricted to be homogenous through all the panel of the units. Therefore, the null hypothesis of non-stationary is expressed as:

$\mathrm{H}_{0}: \gamma_{i}=0$ is tested beside the alternative $\mathrm{H}_{\mathrm{A}}: \gamma_{i}=\gamma<0$ for all $\mathrm{i}$

Where the fixed effect in the equation 4 is based on the usual t-statistic. Finally,

$$
t_{\gamma}=\frac{\left(\gamma^{\wedge}\right)}{\operatorname{s.e}\left(\gamma^{\wedge}\right)}
$$

Where the $\gamma$ is restricted through retained the identical across areas for null and alternative hypothesis.

Table 3. Panel unit root test (Levin, Lin and Chu statistics)

\begin{tabular}{|c|c|c|c|c|c|c|c|}
\hline \multicolumn{8}{|c|}{ Panel Unit root test (Levin, Lin and Chu Statistics) } \\
\hline Variables & Level & M1 & M2 & M3 & M4 & M5 & Inference \\
\hline \multirow[t]{2}{*}{ PGDP } & LED & -8.773 & -1.079 & -3.321 & -1.725 & -1.068 & \\
\hline & FDD & $-23.841 * *$ & $-13.601 * *$ & $-23.985 * *$ & $-14.611 * *$ & $-29.27 * *$ & $\mathrm{I}(1)$ \\
\hline \multirow[t]{2}{*}{ BMS } & LED & -1.164 & & & & & \\
\hline & FDD & $-8.576^{* *}$ & & & & & $\mathrm{I}(1)$ \\
\hline \multirow[t]{2}{*}{ DCB } & LED & & 4.092 & & & & \\
\hline & FDD & & $-13.735^{* *}$ & & & & $\mathrm{I}(1)$ \\
\hline \multirow[t]{2}{*}{ CLA } & LED & & & 0.656 & & & \\
\hline & FDD & & & $-13.689 * *$ & & & $\mathrm{I}(1)$ \\
\hline \multirow[t]{2}{*}{ DCP } & LED & & & & 4.469 & & \\
\hline & FDD & & & & $-10.339 * *$ & & $\mathrm{I}(1)$ \\
\hline \multirow[t]{2}{*}{ LL } & LED & & & & & 5.425 & \\
\hline & FDD & & & & & $-12.876^{* *}$ & $\mathrm{I}(1)$ \\
\hline INF & LED & -6.313 & -6.075 & -5.152 & -5.657 & -4.547 & \\
\hline
\end{tabular}


$\begin{array}{lllllll}\text { FDD } & -17.857 * * & -16.921 * * & -10.26 * & -14.022^{* *} & -17.531 * & \mathrm{I}(1)\end{array}$

$*, * *$ indicates the significance level at 1 and $5 \%$ respectively.

LED represents the level data; FDD represents the first difference data; M1 shows the model 1 (Causal nexus between the PGDP, INF, and BMS); M2 shows the model 2 (Causal nexus between the PGDP, INF, and DCB); M3 shows the model 3 (Causal nexus between the PGDP, INF, and CLA); M4 shows the model 4 (Causal nexus between the PGDP, INF, and DCP); M5 shows the model 5 (Causal nexus between the PGDP, INF, and LL). I (1) shows the integration of order one; All of the above variables are explain in table 1 and used the log form for this analysis.

\subsection{Panel Co-Integration Test}

This study is used panel co-integration test to examine for the existence of ling run equilibrium association between the variables. If the difference among two non-stationary series is stationary, then these series are co-integrated. If these series are co-integrated, it is likely to explain the variables as being in a long run association. In addition, the lack of co-integration advocates that the variable have no long run association which means they might move randomly far away from each other. The term 'co-integrated' are generally used when a group of time series converts the stationary only after being the first-differenced, then the singular time series may have linear mixtures that are stationary without differencing (Engle \& Granger, 1987; Granger, 1988). If the order one of integration is inferred, the next phase is to employ co-intgration scrutiny in order to institute whether there exists a long run association between the probably 'integrated' variables. In such examinations, Johansen's Vector Auto Regression (VAR) test for co-integration in generally employed (Johansen, 1988). The VAR is a systematic methodology to examine for co-integration permitting for the determination of up to $r$ linearly independent co-integrating vectors $(r \leq g-1$, the $g$ is the number of variables which is checked for co-integration). The estimated equation can be expressed as follows:

$$
Y_{i t}=\beta_{i 0}+\beta_{i 1} X_{i 1 t}+\beta_{i 2} X_{i 2 t}+\cdots+\beta_{i k} X_{i k t}+\varepsilon_{i t}
$$

This estimated equation might be rewritten as:

$$
\varepsilon_{i t}=Y_{i t}-\left(\beta_{i 0}+\beta_{i 1} X_{i 1 t}+\beta_{i 2} X_{i 2 t}+\cdots+\beta_{i k} X_{i k t}\right)
$$

the co-integration vector explain as:

$$
\left[1-\beta_{i 0}-\beta_{i 1}-\beta_{i 2}-\cdots-\beta_{i k}\right]
$$

The set up by Johansen (1988), the above test cannot deal with a panel situation. Therefore, this study is used a development, the Pedroni (2004) panel cointegration test for the presence of co-integration between the variables. This test is applied for the time series panel regression as follows: 


$$
\begin{gathered}
Y_{i, t}=\alpha_{i}+\sum_{j=1}^{p i} \beta_{j i} X_{j i t}+\varepsilon_{i t} \\
\varepsilon_{i t}=\rho_{i} \varepsilon_{i}(t-1)+\omega_{i t}
\end{gathered}
$$

Where $\alpha_{i}$ permits for the possibility of particular country specific fixed effects, $\beta_{j i}$ permits for variation through separate countries, $Y_{i, t}$ and $X_{j i t}$ are the perceptible variables and $\varepsilon_{i t}$ shows the error term from the panel regression. The null hypothesis of no co-integration of the pooled assessment is expressed as follows:

$$
\mathrm{H}_{0}: \rho_{i}=1 \text { for all } \mathrm{i} \text { against } \mathrm{H}_{0}: \rho_{i}=\rho<1
$$

The within dimensional assessment in first hypothesis assumes a common value for $\rho_{i}\left(=\rho_{i}\right)$. So, this process dismisses any more source of heterogeneity among the individual country of the particular panel. The null hypothesis of this pooled test (among dimensions) assessment is expressed as follows:

$$
\mathrm{H}_{0}: \rho_{i}=1 \text { for all } \mathrm{i} \text { against } \mathrm{H}_{0}: \rho<1
$$

The alternative hypothesis of the between dimensions assessment does not assume a common value for $\rho_{i}$. It permits for the further source of possible heterogeneity through separate country of the panel.

The Pedroni proposed two categories of tests to examine the presence of heterogeneity for the co-integration vector. The first one is the test which uses the within-dimension method (panel test). This test use the four statistics which are panel (v-statistic, p-statistics, PP-statistic and ADF-statistic). All of these statistics pool the autoregressive coefficients across diverse panel members for the unit root test to be executed on the estimated residuals. The second one is the test which is rely on the among-dimensions method. It contains the three statistics (group p-statictic, group PP-statistic and group ADF-statistic. These statistics are rely on estimators that basically average the separate estimated autoregressive coefficients for each member.

All of the tests assume that the presence of an asymptotically standard normal distribution certain by the particular group/panel co-integration statistic. The panel $v$ is a one-side tests which the large positive values reject the null hypothesis of no co-integration. The others statistics deviate to negative infinitude, which means that more the negative values also reject the null hypothesis. These tests are competent to accommodate the country specific dynamic of short run, country specific fixed effects and also trends, as well as the slope coefficients (Pedroni, 2004).

Table 4. Pedroni panel and Kao cointegration test results

$\begin{array}{lll}\text { No Deterministic } & \text { Kao Test } & \text { Deterministic } \\ \text { intercept/trend } & & \text { intercept/trend }\end{array}$

Model 1: PGDP, INF,

$-4.605[0.000]$ 
BMS

\begin{tabular}{|c|c|c|c|c|c|}
\hline Panel v-statistics & 3.352 & {$[0.000]$} & & -0.061 & [0.524] \\
\hline Panel $\rho$-statistics & -10.861 & {$[0.000]$} & & -9.094 & {$[0.000]$} \\
\hline Panel PP-statistics & -8.489 & {$[0.000]$} & & -10.695 & {$[0.000]$} \\
\hline Panel ADF-statistics & -7.816 & {$[0.000]$} & & -9.699 & [0.000] \\
\hline Group $\rho$-statistics & -13.426 & {$[0.000]$} & & -8.927 & {$[0.000]$} \\
\hline Group PP-statistics & -13.257 & {$[0.000]$} & & -12.586 & {$[0.000]$} \\
\hline Group ADF-statistics & -11.771 & {$[0.000]$} & & -11.021 & {$[0.000]$} \\
\hline $\begin{array}{l}\text { Model 2: PGDP, INF, } \\
\text { DCB }\end{array}$ & & & $-4.628 \quad[0.000]$ & & \\
\hline Panel v-statistics & 2.997 & [0.001] & & -0.283 & [0.611] \\
\hline Panel $\rho$-statistics & -10.671 & {$[0.000]$} & & -9.095 & [0.000] \\
\hline Panel PP-statistics & -8.368 & {$[0.000]$} & & -10.881 & {$[0.000]$} \\
\hline Panel ADF-statistics & -7.725 & {$[0.000]$} & & -9.962 & {$[0.000]$} \\
\hline Group $\rho$-statistics & -13.163 & {$[0.000]$} & & -8.863 & {$[0.000]$} \\
\hline Group PP-statistics & -13.006 & {$[0.000]$} & & -12.899 & {$[0.000]$} \\
\hline Group ADF-statistics & -11.553 & {$[0.000]$} & & -11.352 & [0.000] \\
\hline $\begin{array}{l}\text { Model 3: PGDP, INF, } \\
\text { CLA }\end{array}$ & & & $-6.575[0.000]$ & & \\
\hline Panel v-statistics & 0.927 & {$[0.176]$} & & -1.025 & [0.847] \\
\hline Panel $\rho$-statistics & -9.266 & {$[0.000]$} & & -9.415 & {$[0.000]$} \\
\hline Panel PP-statistics & -7.143 & {$[0.000]$} & & -11.142 & {$[0.000]$} \\
\hline Panel ADF-statistics & -6.565 & {$[0.000]$} & & -10.239 & {$[0.000]$} \\
\hline
\end{tabular}




\begin{tabular}{|c|c|c|c|c|c|}
\hline Group $\rho$-statistics & -10.804 & {$[0.000]$} & & -9.087 & {$[0.000]$} \\
\hline Group PP-statistics & -10.471 & {$[0.000]$} & & -12.913 & {$[0.000]$} \\
\hline Group ADF-statistics & -8.796 & {$[0.000]$} & & -11.395 & {$[0.000]$} \\
\hline $\begin{array}{l}\text { Model 4: PGDP, INF, } \\
\text { DCP }\end{array}$ & & & $-4.778 \quad[0.000]$ & & \\
\hline Panel v-statistics & 4.392 & {$[0.000]$} & & 1.431 & {$[0.076]$} \\
\hline Panel $\rho$-statistics & -10.561 & {$[0.000]$} & & -9.492 & {$[0.000]$} \\
\hline Panel PP-statistics & -8.289 & {$[0.000]$} & & -12.303 & {$[0.000]$} \\
\hline Panel ADF-statistics & -7.704 & {$[0.000]$} & & -9.134 & {$[0.000]$} \\
\hline Group $\rho$-statistics & -13.108 & {$[0.000]$} & & -9.087 & {$[0.000]$} \\
\hline Group PP-statistics & -13.183 & {$[0.000]$} & & -14.474 & {$[0.000]$} \\
\hline Group ADF-statistics & -11.787 & {$[0.000]$} & & -10.716 & {$[0.000]$} \\
\hline $\begin{array}{l}\text { Model 5: PGDP, INF, } \\
\text { LL }\end{array}$ & & & $-5.062 \quad[0.000]$ & & \\
\hline Panel v-statistics & 5.971 & {$[0.000]$} & & 2.011 & {$[0.022]$} \\
\hline Panel $\rho$-statistics & -10.963 & {$[0.000]$} & & -9.428 & {$[0.000]$} \\
\hline Panel PP-statistics & -8.563 & {$[0.000]$} & & -11.202 & {$[0.000]$} \\
\hline Panel ADF-statistics & -7.893 & {$[0.000]$} & & -10.223 & {$[0.000]$} \\
\hline Group $\rho$-statistics & -13.482 & {$[0.000]$} & & -9.122 & {$[0.000]$} \\
\hline Group PP-statistics & -13.281 & {$[0.000]$} & & -12.883 & {$[0.000]$} \\
\hline Group ADF-statistics & -11.775 & {$[0.000]$} & & -11.284 & {$[0.000]$} \\
\hline
\end{tabular}

All of the above variables are explain in table 1 and used the log form for this analysis. All of the figures in square brackets are probability which is shows the level of significance. 
The Cross-sectional dependence (CD) tests designate that the series shows the dependence of cross-sectional. To examine the presence of $\mathrm{CD}$, four different tests $\left(\mathrm{CD}, \mathrm{CD}_{\mathrm{BP}}, \mathrm{CDLM}\right.$, and $\mathrm{LM}_{\mathrm{adj}}$ ) were applied and the results are explained in table 6. The results stated consistently reject the null hypothesis of cross-sectional independence, indicating the cross-sectional dependence in the data given the statistical significance of the CD statistics.

Table 5. Cross-sectional dependence results

\begin{tabular}{ll}
\hline Test & Statistics \\
\hline $\mathrm{CD}$ & $26.5518^{*}$ \\
$\mathrm{CD}_{\mathrm{BP}}$ & $70.0000^{* *}$ \\
$\mathrm{CDLM}$ & 124.8807 \\
$\mathrm{LM}_{\mathrm{adj}}$ & $124.8155^{* *}$ \\
\hline
\end{tabular}

$*$,** Significance at the $1 \%$ and $5 \%$ level

Table 6 shows the panel result of DOLS and FMOLS. All of the coefficients of the banking sector development are positive and statistically significant in all five model, whereas the inflation also negative and significant influence on the economic growth except some models. It means that the development of the banking sector have a substantial effect on the economic growth. Additionally, if the regulator bodies are more emphasis on this banking sector then its lead to a fruitful results which is the good of the economy.

Table 6. Panel long-run DOLS and FMOLS results

\begin{tabular}{lllll}
\hline & $\underline{\text { DOLS }}$ & \multicolumn{3}{c}{ FMOLS } \\
Variables & Coefficient & t-statistic & Coefficient & t-statistic \\
\hline$\underline{\text { M1 }}$ & & & & \\
INF & -0.9460 & $-3.3640^{* *}$ & -0.1017 & $-0.6218^{*}$ \\
BMS & 0.8023 & $6.3855^{* *}$ & 0.5807 & $4.7800^{* *}$ \\
$\underline{\text { M2 }}$ & & & & \\
INF & -0.0655 & $-0.2415^{*}$ & -0.0560 & $-0.3336^{*}$ \\
DCB & 0.8625 & $5.8969^{* *}$ & 0.6412 & $4.6981^{* *}$ \\
\hline
\end{tabular}




$\begin{array}{lllll}\underline{\mathrm{M} 3} & & & & \\ \mathrm{INF} & 0.8727 & 2.4562 & 0.1087 & 0.8018 \\ \mathrm{CLA} & 0.4184 & 7.3034 * * & 0.4015 & 8.2425^{* *} \\ \mathrm{M} 4 & & & & \\ \mathrm{INF} & 0.5296 & 1.9201 & 0.3241 & 2.809690 \\ \mathrm{DCP} & 0.9267 & 7.7749 * * & 0.1357 & 1.8442 *\end{array}$

$\underline{\text { M5 }}$

$\begin{array}{lllll}\text { INF } & -1.2649 & -5.4195 * * & -0.1705 & -1.1466 \\ \text { LL } & 1.2214 & 10.4641 * * & 0.8603 & 6.9533\end{array}$

** And *Significance at the $5 \%$ and $1 \%$ level respectively.

Generally no ingenuous rule for determining the maximum lag length, there are formal model requirements criteria that can based on. The lag structure is permitted to diverge through countries, variables and equation. Therefore, for a comparative large panel like this study, this may increase the calculation burden significantly. After all, this study permits diverse maximum lag lengths for these variables, but do not consent them to diverge through countries. This study estimate each individual equation consequently and select the mixture of lags which minimizes the standard Akaike Information Criterion (AIC) and Schwartz Bayesian Information Criterion (SBC).

Table 7. Granger causality analysis

VECM Granger Causality Test

Model 1: VECM with (PGDPC, INF, BMS)

Ln PGDP Ln INF Ln BMS Long-run Causality ECT(-1)

$\begin{array}{lllll}\text { Ln PGDP } & - & -0.096 & 1.491 & -0.487 * * \\ & & {[0.046]} & {[0.001]} & (-6.546) \\ \text { Ln INF } & 0.096 & - & 0.907 & -0.001 *\end{array}$




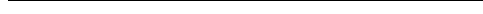

$[0.135]$

Ln BMS

$-0.02$

[0.027]

$(-0.118)$

[0.001]

$[0.025]$

$-0.024^{*}$

$(-3.697)$

Model 2: VECM with (PGDPC, INF, DCB)

Ln PGDP Ln INF Ln DCB Long-run Causality ECT(-1)

\begin{tabular}{|c|c|c|c|c|}
\hline \multirow[t]{2}{*}{ Ln PGDP } & - & -0.184 & 0.488 & $-0.301 * *$ \\
\hline & & [0.014] & {$[0.257]$} & $(-4.508)$ \\
\hline \multirow[t]{2}{*}{ Ln INF } & 0.197 & - & -0.022 & $-0.104 * *$ \\
\hline & {$[0.595]$} & & {$[0.706]$} & $(-3.067)$ \\
\hline \multirow[t]{2}{*}{ Ln DCB } & 0.115 & -0.001 & - & $-0.052 *$ \\
\hline & {$[0.052]$} & [0.869] & & $(-4.901)$ \\
\hline
\end{tabular}

Model 3: VECM with (PGDPC, INF, CLA)

Ln PGDP Ln INF Ln CLA Long-run Causality ECT(-1)

$\begin{array}{lllll}\text { Ln PGDP } & - & 0.102 & 0.091 & -0.271^{* *} \\ & & {[0.206]} & {[0.237]} & (-4.966) \\ \text { Ln INF } & 0.143 & - & 0.039 & -0.171^{*} \\ & {[0.001]} & & {[0.529]} & (-4.389) \\ & 1.028 & -0.09 & - & -0.007^{*} \\ \text { Ln CLA } & {[0.639]} & {[0.032]} & & (-1.674)\end{array}$

Model 4: VECM with (PGDPC, INF, DCP)

Ln PGDP Ln INF Ln DCP Long-run Causality ECT(-1) 


\begin{tabular}{|c|c|c|c|c|}
\hline \multirow[t]{2}{*}{ Ln PGDP } & - & -0.213 & 0.899 & $-0.371 * *$ \\
\hline & & {$[0.003]$} & {$[0.012]$} & $(-5.427)$ \\
\hline \multirow[t]{2}{*}{ Ln INF } & 1.021 & - & 0.423 & $-0.075 * *$ \\
\hline & {$[0.016]$} & & {$[0.172]$} & $(-2.351)$ \\
\hline \multirow[t]{2}{*}{ Ln DCP } & 1.032 & -0.004 & - & $-0.051^{*}$ \\
\hline & [0.021] & [0.671] & & $(-5.125)$ \\
\hline
\end{tabular}

Model 5: VECM with (PGDPC, INF, LL)

Ln PGDP Ln INF Ln LL Long-run Causality ECT(-1)

$\begin{array}{lllll}\text { Ln PGDP } & - & -0.14 & 2.662 & -0.463^{* *} \\ & & & & \\ & & {[0.037]} & {[0.000]} & (-6.467) \\ \text { Ln INF } & 1.045 & - & 0.058 & -0.018 \\ & {[0.048]} & & {[0.895]} & (-1.183) \\ & 1.025 & -0.011 & - & -0.025 \\ \text { Ln LL } & {[0.004]} & {[0.096]} & & (-3.992)\end{array}$

*,** indicates the significance level at 1 and $5 \%$ respectively.

VECM: vector error correction model; ECT: error correction term.

All of the above variables are explain in table 1 and used the log form for this analysis.

Values in the parentheses shows the t-statistics and values in square brackets shows the probabilities for F-statistics. 

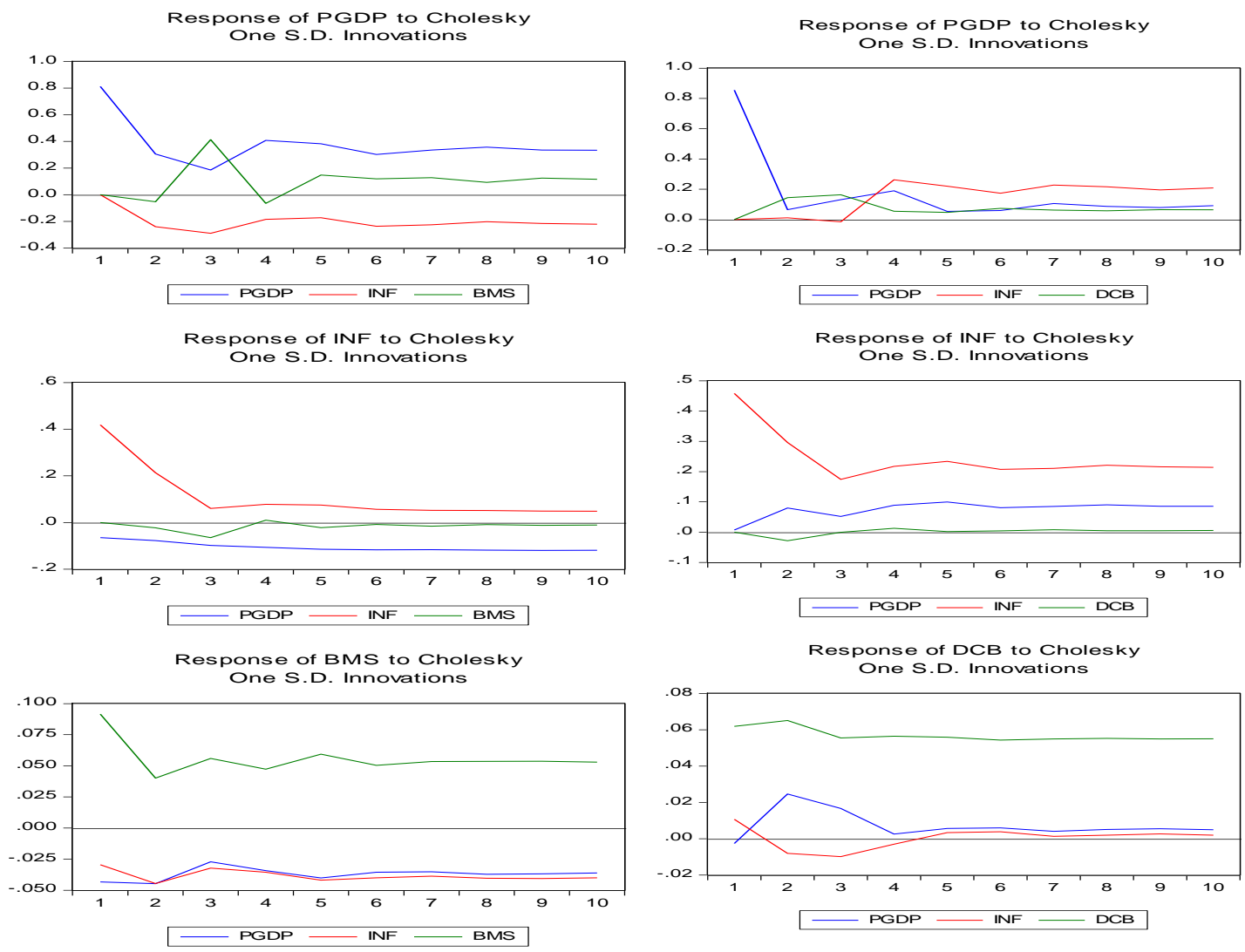

Response of PGDP to Cholesky
One S.D. Innovations
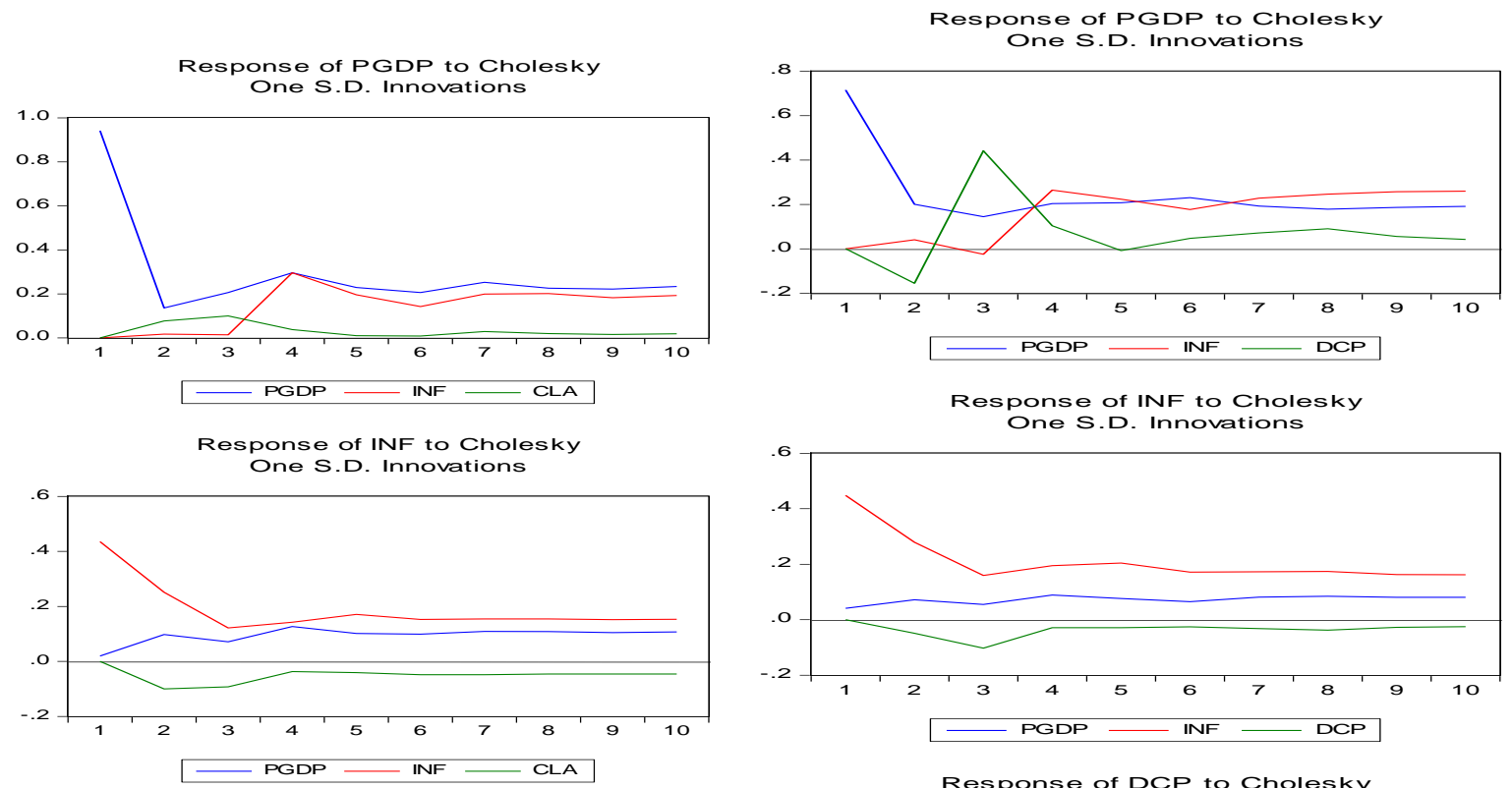

Response of CLA to Cholesky One S.D. Innovations
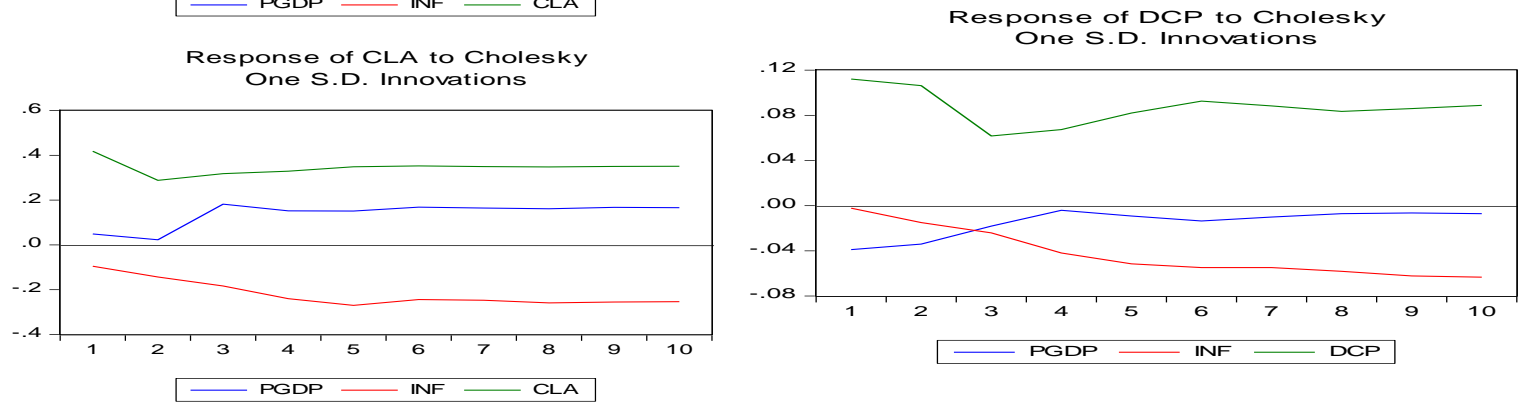


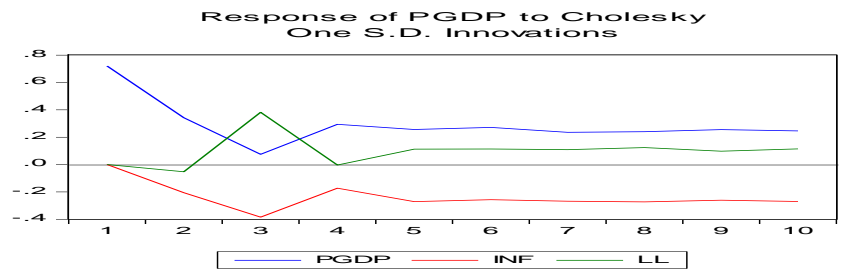

Response of inf to Cholesky

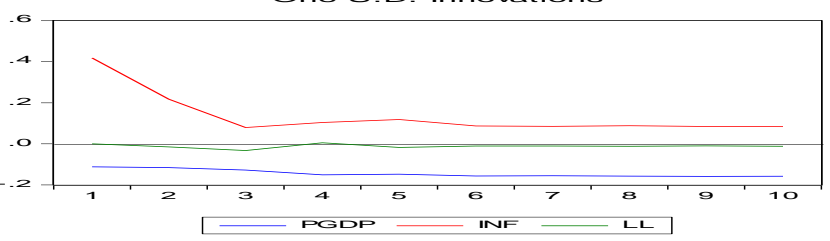

Response of LL to Cholesky

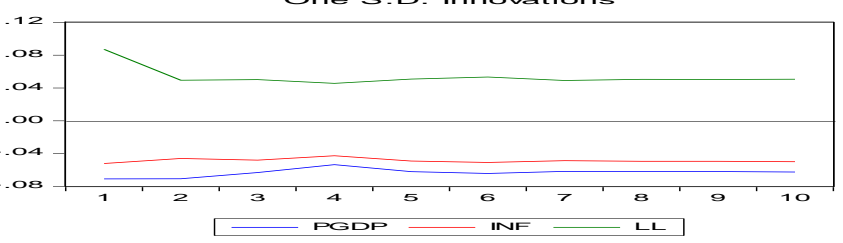

Figure 2. Generalized Impulse Response Function (GIRFs) for all models

\section{Empirical Results and Discussion}

The experimental outcomes contributes in a three phases. Firstly, this study provide an indication on the nature of level of stationary of all the variables. Secondly, this study delivers the results regarding the cointegration between the variables and finally, the results of the direction of Granger causality among the cointegrated variables.

The assessment procedure encompasses the scrutinizing the five different cases, which is symbolized by model 1 to model 5. In each of case implements a different banking region development indicator. In model 1 (M1) explains the causal nexus between the economic growth, inflation and the broader money supply (BMS). Model 2 (M2) describes the causal relation between the economic growth, inflation and the domestic credit provided by the banking region (DCB). In model 3 (M3) deals with a relation between the economic growth, inflation and the claim on assets (CLA). Model 4 (M4) explores the causal connection among the economic growth, inflation, and the domestic credit to private region (DPS). Finally, in the model 5 (M5) is concerning with the causal connection between the economic growth, inflation, and the liquid liabilities (LL).

Table 3 and 4 indicate that all the variables are integrated of order one, which means they become stationary after the first difference and also the cointegrated. The results of this study expose the presence of short run causality among the variables, then this study explain in a detail on the long run causal relationships by using the table 5. The presence of I (1) and cointgreation between all the variables involve the chances of Granger causality between them. Therefore, this study execute a causality analysis by a vector error correction model and using the all three equation. Table 5 explains the panel Granger causality analysis outcomes for short run, symbolized by the significance of the F-statistics, and the long run represented by the significance of error correction term. 


\section{MInstitute Mach $^{m}$}

International Journal of Accounting and Financial Reporting

ISSN 2162-3082

2018, Vol. 8, No. 4

Table 5, all the five models, when the change in PGDP works as a dependent variable, the lagged error correction term is negative and statistically significant. This indicates that the PGDP inclines to congregate to its long run equilibrium way in reaction to a changes in its regressors. This results confirms the presence of long run equilibrium among the PGDP, inflation, and the five indicators of baking sector development. In other words, this study determine that the inflation, and the indicators of banking development Granger cause the growth in the long run. The lagged error correction term is negative and significant in all model except the model 5, which is the economic growth, inflation, and liquid liabilities (one of the indicator of banking development). It means there exists a long run causality and a bidirectional causality among the economic growth and all indicators of banking development except the liquid liabilities.

Finally, to accompaniment our analysis, this study employ the generalized impulse response function to trace the influence of a one-off shock to one of the innovation on the current and upcoming values of the endogenous variables. This impulse responses offer further perception into how shocks to each indicators of banking region enlargement can affect and be affected by the inflation and growth. All of these outcomes are graphed in figure one for individual banking region development indicators. This exploration offers further sustenance for the outcomes of this research.

\section{Conclusion}

The financial system has become a prominently more intricate over the past decades as the separation among the mutual funds, insurance organizations, banks, and suppliers have distorted their relevant assistances to the world economy. This has happened generally due to financial dissemination, digital revolution and the deregulation. Though such complication is an inevitable magnitude of more competition, assimilation of economies to the world economy and amassed the economic affluence across the world, this has occasioned in an increasing the interlocking and interdependence between all of these different markets (Billio et al., 2012).

In this paper, we scrutinize the interdependence between the banking region improvement, inflation and the economic growth in the six Asian countries using time series data from 1970 to 2016. Using the panel co-integration methods, we confirmation that there is a long run equilibrium relationship between all of the variables, but the nature of the causal relationship is intricate in that particularly the inflation and some indicator of banking region improvement Granger-cause the economic growth in the long run. Therefore, we are able to institute the presence of reverse causality among the growth and the first four indicators of banking region development in the long run. In the same way, we find results is support of all possible four hypothesis (the supply leading, the demand following, the feedback, and the neutrality hypotheses). These findings are consistent with the (Al-Yousif, 2002; Pradhan et al., 2013b; 2014c; Menyah et al., 2014).

From a policy perception, to confirm the continued economic growth in the six Asian countries, the efforts should be concentrated to incessantly progress of the banking region, which are increasingly becoming integrated due to congregating high-tech stages. To confirm 
the countries continue to progress the virtual ecosystems that enable the banking organizations to prolong their influence and abundance of their services, the important stakeholders (banks, regulatory bodies, government) should undertake a number of modifications to extend the influence of the banking structure on the economic growth of the Asian countries. Firstly, the policy makers should confirm that the sufficient provisions are made in the national budget to give state-of-the-art ICT service and the literacy program to empower the people of all sectors of the population to have access the worldwide information and the information networks. Secondly, the banking organizations can play a significance role in amassed the level of financial learning of their clients, particularly those from the relegated groups, by giving a user-friendly technology, online lectures to access these financial services. All of these actions will lessen the time for customers and organizations in retrieving the concerning information what they have require. Thirdly, the banking organizations can also act as consultants and business partners for SMEs by serving them to accomplish their risk and deliver insights on escalating their business processes. The financial organizations with a wide custom can also play an important role in concerning organizations that accompaniment one another's business progress plans. These creativities will help the banks institutions to build the confidence and encourage the strong customer relations, which lead to supportable business partnership that will advantage all stakeholders in the economy. Further studies can consider to use different indicators to measure the development of the banking sector and also future research can examination the relationship between the development of banking sector, any more macro-economic variables, and the economic growth in other emerging market economies to compare the findings with the ones of this study.

\section{References}

Abu-Bader, S., \& Abu-Qarn, A. (2008b). Financial development and economic growth: the Egyptian experience. Journal of Policy Modelling, 30, 887-98.

Adam, C., \& Bevan, D. (2005). Fiscal deficits and growth in developing countries. Journal of Public Economics, 89, 571-597.

Ahmed, S., \& Ansari, M. (1998). Financial sector development and economic growth: the South-Asian experience. Journal of Asian Economics, 9, 503-517.

Al-Yousif, Y. (2002). Financial Development and Economic Growth : Another Look at the. Evidence from Developing Countries. Review of Financial Economics, 11(2), 131-150.

Andres, J., Hernando, I., \& Lopez-Salido, J. (2004). The role of the financial system in the growth-inflation link: the OECD experience. European Journal of Political Economy, 20, 941-961.

Ang, J. (2008). Survey of recent developments in the literature of finance and growth. Journal of Economic Surveys, 22, 536-576.

Ang, J., \& McKibbin, W. (2007). Financial liberalization, financial sector development and growth: evidence from Malaysia?. Journal of Development Economics, 84, 215-233. 


\section{$\triangle 1$ Macrothink}

International Journal of Accounting and Financial Reporting

ISSN 2162-3082

2018, Vol. 8, No. 4

Arai, M., Kinnwall, M., \& Thoursie, P. (2004). Cyclical and causal patterns of inflation and GDP growth. Applied Economics, 36, 1705-1715.

Barro, R., \& Sala-i-Martin, X. (1995). Economic Growth. New York: McGraw Hill.

Beck, T., \& Levine, R. (2004). Stock markets, banks and growth: Panel Evidence. Journal of Banking Finance, 28, 423-42.

Beck, T., Levine, R., \& Loayza, N. (2000). Finance and source of Growth. Journal of Financial Economics, 58, 261-300.

Billio, M., Getmansky, M., Lo, A., \& Pelizzon, L. (2012). Econometric Measures of Connectedness and Systemic Risk in the Finance and Insurance Sectors. Journal of Financial Economics, 104(3), 535-559.

Bojanic, A. (2012). The impact of financial development and trade on the economic growth of Bolivia. Journal of Applied Economics, 15, 51-70.

Calderon, C., \& Liu, L. (2003). The direction of causality between financial development and economic growth. Journal of Development Economics, 72, 321-34.

Chaiechi, T. (2012). Financial development shocks and contemporaneous feedback effect on key macroeconomic indicators: a post Keynesian time series analysis. Economic Modelling, $29,487-501$

Chang, T., \& Caudill, S. (2005). Financial development and economic growth: the case of Taiwan. Applied Economics, 37, 1329-1335.

Christopoulos, D., \& Tsionas, E. (2004). Financial development and ec onomic growth: evidence from panel unit root and cointegration tests. Journal of Development Economics, 73, $55-74$.

Engle, R., \& Granger, C. (1987). Cointegration and error correction: representation, estimation and testing. Econometrica, 55, 251-276.

Fountas, S., \& Karanasos, M. (2007). Inflation, output growth, and nominal and real uncertainty: empirical evidence for the G7. Journal of International Money and Finance, 26, 229-250.

Ghirmay, T. (2004). Financial development and economic growth in sub-Saharan African countries: evidence from time series analysis. African Development Review, 16, 415-432.

Goldsmith, R. (1969). Financial Structure and Development. New Haven, CT: Yale University Press.

Granger, C. (1988). Some recent developments in a concept of causality. Journal of Econometrics, 39, 199-211.

Gries, T., Kraft, M., \& Meierrieks, D. (2009). Linkages between financial deepening, trade openness, and economic development: causality evidence from sub-Saharan Africa. World Development, 37, 1849-1860. 


\section{Macrothink}

International Journal of Accounting and Financial Reporting

ISSN 2162-3082 2018, Vol. 8, No. 4

Hassan, K., Sanchez, B., \& Yu, J. (2011). Financial development and economic growth: new evidence from panel data. The Quarterly Review of Economics and Finance, 51, 88-104.

Holtz-Eakin, D., Newey, W., \& Rosen, H. (1988). Estimating vector auto regressions with panel data. Econometrica, 56, 1371-95.

Hsueh, S., Hu, Y., \& Tu, C. (2013). Economic growth and financial development in Asian countries: a bootstrap panel granger causality analysis. Economic Modelling, 32, 294-301.

Hwang, Y. (2001). Relationship between inflation rate and inflation uncertainty. Economics Letters, 73, 179-186.

Johansen, S. (1988). Statistical analysis of cointegration vectors. Journal of Economic Dynamics and Control, 12, 231-254.

Kar, M., Nazlioglu, S., \& Agir, H. (2011). Financial developmentment and economic growth Nexus in the MENA countries: bootstrap panel granger causality analysis. Economic Modelling, 28, 685-693.

Khan, A. (2001). Financial development and economic growth. Macroeconomics Dynamics, $5,413-433$.

King, R., \& Levine, R. (1993a). Finance and growth: Schumpeter might be right. The Quarterly Journal of Economics, 108, 717-737.

King, R., \& Levine, R. (1993b). Finance, entrepreneurship and economic growth: theory and evidence. Journal of Monetary Economics, 32, 513-42.

Levine, A., Lin, C., \& Chu, C. (2002). Unit root tests in panel data: asymptotic and finite sample properties. Journal of Econometrics, 108, 1-24.

Levine, R. (2003). More on finance and growth: more finance, more growth? Federal Reserve Bank of St. Louis Review, 85, 31-46.

Levine, R. (2005). Finance and growth: Theory, evidence and mechanisms. In Handbook of economic growth (Vol. 1). Amsterdam: Elsevier B.V.

Levine, R., Loayza, N., \& Beck, T. (2000). Financial intermediation and growth: causality analysis and causes. Journal of Monetary Economics, 46, 31-77.

Liang, Q., \& Teng, J. (2006). Financial development and economic growth: evidence from China. China Economic Review, 17, 395-411.

Menyah, K., Nazlioglu, S., \& Wolde-Rufael, Y. (2014). Financial Development, Trade Openness and Economic Growth in African Countries: New Insights from a Panel Causality Approach. Economic Modelling, 37(2), 386-394.

Naceur, S., \& Ghazouani, S. (2007). Stock markets, banks, and economic growth: empirical evidence from the MENA region. Research in International Business and Finance, 21, 297-315. 


\section{Macrothink}

International Journal of Accounting and Financial Reporting

ISSN 2162-3082

2018, Vol. 8, No. 4

Nguyen, T., \& Wang, K. (2010). Causality between housing returns, inflation and economic growth with endogenous breaks. Journal of Chinese Economic and Business Studies, 8, 95-115.

Odhiambo, N. (2007). Supply-leading versus demand following hypotheses: empirical evidence from three SSA countries. African Development Review, 19, 257-280.

Odhiambo, N. (2008). Financial development in Kenya: a dynamic test of the finance-led growth hypotheses. Economic Issues, 13, 21-36.

Pedroni, P. (1999). Critical values for cointegration tests in heterogeneous panels with multiple regressors. Bulletin of Economics and Statistics, 61, 653-670.

Pedroni, P. (2000). Fully modified OLS for heterogeneous cointegrated panels. Advances in Econometrics, 15, 93-130.

Pedroni, P. (2004). Panel cointegration: asymptotic and finite sample properties of pooled time series tests with an application to the PPP hypothesis: new results. Econometric Theory, 20, 597-627.

Petkovsk, M., \& Kjosevsk, J. (2014). Does banking sector development promote economic growth? An empirical analysis for selected countries in Central and South Eastern Europe. Economic Research-Ekonomska Istra, 27(1), 55-66.

Pradhan, R., Dasgupta, P., \& Samadhan, B. (2013a). Finance development and economic growth in BRICS: a panel data. Journal of Quantitative Economics, 11, 308-322.

Pradhan, R., Mukhopadhyay, B., Gunashekar, A., Bele, S., \& Pandey, S. (2013b). Financial Development, Social Development, and Economic Growth: The Causal Nexus in Asia. Decision, 40(1-2), 69-83.

Pradhan, R., Tripathy, S., Chatterjee, D., Zaki, D., \& Mukhopadhyay, B. (2014c). Development of Banking Sector and Economic Growth: The ARF Experience. Decision, 41(3), 245-259.

Quartey, P., \& Prah, F. (2008). Financial development and economic growth in Ghana: is there a causal link?. African Finance Journal, 10, 28-54.

Rousseau, P., \& Wachtel, P. (1998). Financial intermediation and economic performance: historical evidence from five industrialized countries. Journal of Money, Credit and Banking, $34,657-78$.

Shan, J., Morris, A., \& Sun, F. (2001). Financial development and economic growth: an egg-chicken problem?. Review of International Economics, 9, 443-454.

Sunde, T. (2012). Financial sector development and economic growth nexus in South Africa. International Journal of Monetary Economics and Finance, 5, 64-75.

Trew, A. (2006). Finance and growth: a critical survey. Economic Record, 82, 481-490. 


\section{Macrothink}

International Journal of Accounting and Financial Reporting ISSN 2162-3082 2018, Vol. 8, No. 4

Wolde-Rufael, Y. (2009). Re-examining the financial development and economic growth nexus in Kenya. Economic Modelling, 1140-6.

Wu, J., Hou, H., \& Cheng, S. (2010). The dynamic impacts of financial institutions on economic growth: evidence from the European union. Journal of Macroeconomics, 32, 879-891.

Zaman, K., Izhar, Z., Khan, M., \& Ahmad, M. (2012). The Relationship between Financial Indicators and Human Development in Pakistan. Economic Modelling, 29(5), 1515-1523.

Zhang, J., Wang, L., \& Wang, S. (2012). Financial development and economic growth: recent evidence from China. Journal of Comparative Economics, 40, 393-412.

\section{Copyright Disclaimer}

Copyright for this article is retained by the author(s), with first publication rights granted to the journal.

This is an open-access article distributed under the terms and conditions of the Creative Commons Attribution license (http://creativecommons.org/licenses/by/4.0/) 